\title{
SURVEY KETERLAKSANAAN PEMBELAJARAN PENDIDIKAN JASMANI OLAHRAGA DAN KESEHATAN (PJOK) BERBASIS DARING TINGKAT SMP
}

\author{
I Ketut Okta Pradipta Jaya ${ }^{1}$, I Ketut Yoda ${ }^{2}$, I Ketut Iwan Swadesi ${ }^{3}$ \\ ${ }^{1}$ Pendidikan Olahraga Program Pascasarjana Universitas Pendidikan Ganesha, \\ Singaraja, Indonesia \\ ${ }^{2}$ IImu Keolahragaan Universitas Pendidikan Ganesha, \\ Singaraja, Indonesia \\ ${ }^{3}$ IImu Keolahragaan Universitas Pendidikan Ganesha, \\ Singaraja, Indonesia
}

email: oktapradiptajaya@undiksha.ac.id, yodaketut@undiksha.ac.id, iwan.swadesi@undiksha.ac.id

\begin{abstract}
Abstrak
Penelitian ini bertujuan untuk mendeskripsikan keterlaksanaan pembelajaran pendidikan jasmani olahraga Kesehatan berbasis daring tingkat SMP di kabupaten Bangli pada masa pandemi Covid- 19 . Populasi dalam penelitian ini adalah guru PJOK SMP di kabupaten Bangli berjumlah 57 orang dan siswa berjumlah 228 orang, sehingga populasi sebanyak 285 orang. Penentuan sampel penelitian ini menggunakan teknik Quota Sampling, dengan sampel sebanyak 95 orang terdiri dari 19 guru PJOK dan 76 siswa. Penelitian ini dirancang dalam bentuk deskriptif kuantitatif dengan pendekatan one shot case study. Data penelitian dikumpulkan menggunakan kuesioner yang disebar melalui link google form. Analisis data menggunakan teknik analisis statistik deskriptif dengan data persentase. Hasil penelitian menunjukkan keterlaksanaan pembelajaran PJOK berbasis daring tingkat SMP di Kabupaten Bangli diperoleh rata-rata sebesar $75,9 \%$. Bila dikonversikan ke dalam tabel skala penilaian berada pada kategori "Sedang". Berdasarkan hasil tersebut, pembelajaran PJOK berbasis daring tingkat SMP di Kabupaten Bangli pada masa pandemi Covid-19 terlaksana.
\end{abstract}

Kata Kunci : Keterlaksanaan, Pembelajaran PJOK, Daring, Covid-19

\begin{abstract}
This study was aimed to describe the implementation of learning physical education for health sports online at the junior high school students in Bangli district during the Covid-19 pandemic. The populations in this study were 57 junior high school PJOK teachers in Bangli Regency and 228 students, so the total population was 285 people. The determination of the sample in this study used the Quota Sampling technique, with a sample of 95 people consisting of 19 PJOK teachers and 76 junior high school students in Bangli Regency. This research was designed in the form of a quantitative descriptive study with a one shot case study approach. The data in this study were collected using an online-based PJOK learning implementation questionnaire which was distributed via a google form link. Then, the data obtained were analyzed by using descriptive statistical analysis techniques along with the percentage data. The result shows that the implementation of online-based PJOK learning at the junior high school level in Bangli Regency was $75,9 \%$. When converted into a table the rating scale is in the "Medium" category. Based on the result, it can be concluded that online learning of PJOK at the junior high school level in Bangli Regency during the Covid-19 pandemic was carried out.
\end{abstract}

Keywords: Implementation, Physical Education, Online, Covid-19

\section{PENDAHULUAN}

Pendidikan merupakan proses interaksi antara dua elemen atau lebih melalui berbagai proses untuk mencapai tujuan. Di mana melalui pendidikan seseorang mendapatkan ilmu, pengalaman, wawasan dan dapat meningkatkan derajat serta mendapatkan kedudukan di kalangan masyarakat. Pendidikan Jasmani Olahraga dan Kesehatan adalah proses pendidikan 
yang memanfaatkan aktivitas fisik untuk memperoleh kemampuan individu, baik dalam hal fisik, mental serta emosional (Rahayu, 2013)

Pendidikan jasmani adalah proses pendidikan melalui penyediaan pengalaman belajar kepada siswa yang berupa aktivitas jasmani, bermain dan berolahraga yang direncanakan secara sistematis untuk merangsang pertumbuhan dan perkembangan fisik, keterampilan motorik, keterampilan berfikir, emosional, sosial, dan moral, pembekalan pengalaman belajar itu diarahkan untuk membina, sekaligus membentuk gaya hidup sehat dan aktif sepanjang hayat(Rochman et al., 2020)

Pendidikan Jasmani Olahraga dan Kesehatan (PJOK) pada dasarnya merupakan bagian integral dari sistem pendidikan secara keseluruhan, yang bertujuan untuk mengembangkan aspek kesehatan, kebugaran jasmani, keterampilan berpikir secara kritis, stabilitas emosional keterampilan sosial, penalaran, dan tindakan moral melalui aktivitas jasmani dan olahraga. Hal ini sesuai dengan tujuan pendidikan PJOK yang merupakan media pendorong perkembangan keterampilan motorik, kemampuan fisik, pengetahuan, sikap sportifitas, pembiasaan pola hidup sehat dan pembentukan karakter (mental, emosional, spiritual dan sosial). (Kanca, 2010) menyatakan bahwa pembelajaran PJOK dilakukan dengan karakter pembelajaran yang unik (khas) dibandingkan pembelajaran umum lainnya, sehingga menuntut adanya keahlian khusus bagi seseorang yang berprofesi sebagai guru PJOK.

Pelaksanaan kegiatan pendidikan yang baik harus mengacu pada kurikulum, tidak terkecuali PJOK yang mengacu pada kurikulum 2013. Salah satu mata pelajaran yang diajarkan di sekolah dalam kurikulum 2013 ini adalah PJOK. Pembelajaran PJOK pada umumnya didominasi oleh gerakan fisik yang dilaksanakan di ruangan terbuka atau di lapangan. Pada masa pandemi Covid-19 pelaksanaan pembelajaran PJOK yang semula dilakukan secara tatap muka, kini pembelajaran PJOK harus dilaksanakan secara daring/jarak jauh.

Corona Virus Disease 2019 (Covid-19) adalah penyakit jenis baru yang belum pernah diidentifikasi sebelumnya pada manusia. Pada tanggal 30 Januari 2020 World Health Organization (WHO) telah menetapkan sebagai kedaruratan kesehatan masyarakat yang meresahkan dunia. Pada tanggal 18 Maret 2020 pemerintah mengeluarkan surat edaran tentang segala kegiatan di dalam dan di luar ruangan di semua sektor sementara waktu ditunda demi mengurangi penyebaran Covid-19 terutama pada bidang pendidikan. Kemudian pada tanggal 24 Maret 2020 Mendikbud mengeluarkan Surat Edaran Nomor 4 Tahun 2020 tentang Pelaksanaan Kebijakan Pendidikan dalam Masa Darurat Penyebaran Covid-19. Surat edaran tersebut dijelaskan bahwa proses belajar dilaksanakan di rumah melalui pembelajaran daring/jarak jauh untuk memberikan pengalaman belajar yang bermakna bagi siswa, tanpa terbebani tuntutan menuntaskan seluruh capaian kurikulum untuk kenaikan kelas maupun kelulusan. Proses belajar dari rumah dapat difokuskan pada pendidikan kecakapan hidup antara lain mengenai pandemi Covid-19. Hal ini menjadi salah satu langkah pemerintah dalam upaya memutus tali penyebaran Covid-19 di Indonesia.

Pembelajaran daring merupakan pemanfaatan jaringan internet dalam proses pembelajaran. Adanya pembelajaran daring menjadikan peserta didik memiliki waktu belajar yang leluasa, peserta didik dapat belajar di manapun dan kapanpun. Peserta didik dapat berinteraksi dengan guru melalui beberapa aplikasi yang sudah ada antara lain dengan aplikasi classroom, video converence, telepon atau live chat, zoom, maupun dengan melalui whatsapp group. Pembelajaran daring ini merupakan inovasi dari pendidikan untuk menjawab tantangan akan ketersediaan sumber belajar yang variatif. Menerut (Candra, 2021) pembelajaran daring dapat dipahami sebagai pendidikan formal yang diselenggarakan oleh sekolah yang peserta didik dan guru berada di lokasi yang terpisah sehingga memerlukan telekomunikasi alternatif untuk menghubungkan keduanya dan berbagai sumber daya yang diperlukan didalamnya.

Pelaksanaan pembelajaran di SMP juga menggunakan pembelajaran daring/jarak jauh guru bekerjasama dengan orang tua peserta didik. Keberhasilan suatu model atau media pembelajaran tergantung dari karakteristik peserta didiknya. Hal ini sesuai dengan apa yang diungkapkan oleh Nakayama bahwa dari semua literatur dalam e-learning mengindikasikan 
bahwa tidak semua peserta didik akan sukses dalam pembelajaran online. Karena faktor lingkungan belajar dan karakteristik peserta didik yang mempengaruhinya (Nakayama et al., 2007)

Pada masa pandemi Covid-19 ini pembelajaran PJOK memiliki hambatan dan keterbatasan dalam mengakses internet maupun kemampuan dalam menggunakan fitur-fitur online yang dapat mendukung pelaksanaan pembelajaran daring. Kemudian pelaksanaan pembelajaran PJOK di tingkat SMP yang semula dilakukan secara bertatap muka langsung, kini pembelajaran PJOK dilaksanakan secara daring/jarak jauh. Banyak guru mengimplementasikan dengan cara-cara beragam belajar di rumah, dari perbedaan belajar itu basisnya tetap pembelajaran secara daring. Ada yang menggunakan konsep ceramah online, ada yang tetap mengajar di kelas seperti biasa tetapi divideokan kemudian dikirim ke aplikasi whatsapp siswa, ada juga yang memanfaatkan konten-konten gratis dari berbagai sumber. (Pohan, 2020). Hal ini tentunya berdampak pada pelaksanaan pembelajaran PJOK di tingkat SMP mengenai pelaksanaan pembelajaran PJOK yang disesuaikan dengan kondisi pandemi, peserta didik dan orang tua yang mengeluh akan banyaknya tugas yang diberikan oleh guru, orang tua mengalami kesulitan dalam mendampingi anaknya belajar secara daring, beberapa peserta didik mengalami dan memiliki keterbatasan jaringan internet, dan tidak semua peserta didik memiliki alat komunikasi (handpone) yang memadai.

Berdasarkan permasalahan tersebut, diperlukan gambaran mengenai keterlaksanaan pembelajaran PJOK pada masa pandemi Covid-19 sehingga dapat diketahui seajuh mana keterlaksanaan pembelajaran PJOK dapat terlaksana. Berdasarkan paparan di atas maka peneliti sangat tertarik untuk mengetahui keterlaksanaan pembelajaran Pendidikan Jasamani Olahraga dan Kesehatan (PJOK) berbasis daring pada masa pandemi Covid-19 tingkat SMP di Kabupaten Bangli.

\section{METODE}

Rancangan penelitian adalah rencana tentang bagaimana cara mengumpulkan, menyajikan, dan menganalisis data untuk memberikan arti terhadap data tersebut secara efektif dan efisien (Kanca, 2010). ). Penelitian ini termasuk penelitian deskriptif kuantitatif dengan pendekatan one shot case study dengan satu kali pengumpulan data. Menurut (Sudijono, 2001) penelitian deskriptif adalah penelitian yang bertujuan untuk menggambarkan atau memaparkan suatu hal misalnya keadaan, situasi, peristiwa, dan lainnya. Metode yang digunakan dalam penelitian ini adalah metode survey. Sedangkan pengumpulan datanya menggunakan kuesioner. Penelitian ini dilakukan pada masa pandemi Covid-19, sehingga peneliti memberikan kuesioner secara online melalui google form.

Dalam penelitian ini pengambilan sampel menggunakan non random sampling yang dilakukan dengan cara Quota Sampling yang artinya teknik pengambilan sampel dengan cara menetapkan jumlah tertentu sebagai target yang harus dipenuhi dalam pengambilan sampel dari populasi (khususnya yang tidak terhingga atau tidak jelas), kemudian dengan patokan jumlah tersebut, peneliti mengambil sampel secara sembarang asal memenuhi persyaratan sebagai sampel dari populasi tersebut (Sari et al., 2020). Pada penelitian ini jumalah sampel yang menjadi responden yaitu sebanyak 95 orang yang terdiri dari 19 orang guru PJOK dan 76 orang siswa tingkat SMP di Kabupaten Bangli.

Cara pengumpulan data dilakukan dengan menggunakan instrumen penelitian berupa angket untuk menganalisis keterlaksanaan pembelajaran PJOK berbasis daring tingkat SMP di Kabupaten Bangli pada masa pandemi Covid-19. Penilaian berupa angket ini berisi 30 butir pernyataan, angket yang akan digunakan penelitian terdiri dari butir-butir pernyataan mengenai keterlaksanaan pembelajaran PJOK pada masa pandemi Covid-19. 
Tabel 1. Kisi-kisi Kuesioner

\begin{tabular}{|c|c|c|c|}
\hline Variabel & Indikator & Deskriptor & Butir Soal \\
\hline \multirow{14}{*}{$\begin{array}{l}\text { Faktor-faktor yang } \\
\text { mendukung } \\
\text { keteraaksanaan } \\
\text { pembelajaran PJOK }\end{array}$} & Siswa & Bakat Siswa & 1,2 \\
\hline & & Motivasi Siswa & $3^{*}, 4^{*}$ \\
\hline & & Kondisi Kesehatan & $5^{*}, 6$ \\
\hline & & Sikap/Prilaku Siswa & $7,8^{*}$ \\
\hline & Guru & Penguasaan Materi & 9 \\
\hline & & Kualifikasi Akademik & 10,11 \\
\hline & & Sikap Guru & $12^{*}, 13$ \\
\hline & & Metode Mengajar & 14,15 \\
\hline & & Kreativitas Guru & 16,17 \\
\hline & Kurikulum & Bobot pelajaran & 18 \\
\hline & & Alokasi waktu & 19 \\
\hline & & Bentuk atau susunan & $20,21,22,23$ \\
\hline & Sarana dan & Alat komunikasi & $24,25,26,27^{*}$ \\
\hline & prasarana & Akses internet & $28,29,30$ \\
\hline
\end{tabular}

Teknik pengumpulan data yang digunakan dalam penelitian ini adalah dengan cara melakukan survey keterlaksanaan pembelajaran PJOK berbasis daring tingkat SMP di Kabupaten Bangli pada masa pandemi Covid-19. Penelitian ini menggunakan teknik analisis data deskriptif kuantitatif dengan data presentse yang digunakan untuk mengkaji variabel penelitian yaitu survey keterlaksanaan pembelajaran PJOK di masa pandemi Covid-19. Penelitian ini menggunakan rumus presentase yang sesuai dengan Anas Sudijono 2011 : 43) yaitu sebagai berikut:

$$
\mathrm{P}=\frac{F}{N} \times 100 \%
$$

Keterangan:

$\mathrm{P}=$ Presentase

$\mathrm{F}=$ Frekuensi

$\mathrm{N}=$ Number of Cases (Jumlah frekuensi/ banyaknya individu)

Analisis deskriptif yang digunakan untuk mengetahui keterlaksanaan pembelajaran PJOK berbasis daring tingkat SMP di Kabupaten Bangli pada masa pandemi Covid-19 yang berdasarkan deskriptif frekuensi, sehingga diketahui frekuensi, persentase, dan nilai dengan interval kategori pada tabel 2.

Tabel 2. Skala Penilaian atau Kategori

\begin{tabular}{cccc} 
No & Kriteria & Rentangan & Katagori \\
\hline 1. & $\mathrm{Mi}+1.5 \mathrm{SDi}, \leq \mathrm{Mi}+3.0 \mathrm{Sdi}$ & $97,5 \leq 120$ & Sangat Tinggi \\
\hline 2. & $\mathrm{Mi}+0,5 \mathrm{SDi} \leq \mathrm{Mi}+1,5 \mathrm{Sdi}$ & $82,5 \leq 97,5$ & Tinggi \\
\hline 3. & $\mathrm{Mi}-0,5 \mathrm{SDi} \leq \mathrm{Mi}+0,5 \mathrm{SDi}$ & $67,5 \leq 82,5$ & Sedang \\
\hline 4. & $\mathrm{Mi}-1,5 \mathrm{SDi} \leq \mathrm{Mi}-0,5 \mathrm{SDi}$ & $52,5 \leq 67,5$ & Rendah \\
\hline 5. & $\mathrm{Mi}-3.0 \mathrm{SDi} \leq \mathrm{Mi}-1.5 \mathrm{SDi}$ & $30 \leq 52,5$ & Sangat Rendah \\
\hline
\end{tabular}

Keterangan :

Nilai Max = skor $\max \mathrm{X}$ jumlah pernyataan

$=4 \times 30$

$=120$

Nilai Min $=$ skor $\min \mathrm{X}$ jumlah pernyataan

$=1 \times 30$

$=30$ 
$\mathrm{Mi} \quad=1 / 2 \times($ nilai $\max +$ nilai $\min )$

$=1 / 2 \times 150$

$=75$

$\mathrm{SDi}=16 \times($ nilai $\max -$ nilai $\min )$

$=16 \times 90$

$=15$

Untuk memperoleh dan mengetahui seberapa besar keterlaksanaan pembelajaran PJOK berbasis daring tingkat SMP di Kabupaten Bangli pada masa pandemi Covid-19 ditentukan dengan penghitungan skor tertinggi dari pernyataan guru dan siswa dengan menggunakan rumus sebagai berikut :

Rata-rata $=\frac{\bar{X} 1+\bar{X} 2}{2}$

Keterangan :

$\bar{X} 1 \quad=$ rata-rata pernyataan guru

$\bar{X} 2=$ rata-rata pernyataan siswa

\section{HASIL DAN PEMBAHASAN \\ Hasil}

Berdasarkan hasil pernyataan yang diberikan oleh guru dan siswa melalui angket yang dikirimkan melalui google form. Maka diperoleh rekaptulasi hasil dari jawaban responden sebagai berikut:

Tabel 3. Rekaptulasi Hasil Jawaban Responden

\begin{tabular}{|c|c|c|c|}
\hline NO & PERNYATAAN KUESIONER & GURU & SISWA \\
\hline 1 & $\begin{array}{l}\text { Dalam satu kelas siswa memiliki bakat olahraga yang bermacam- } \\
\text { macam }\end{array}$ & $84,2 \%$ & $85,5 \%$ \\
\hline 2 & $\begin{array}{l}\text { Dalam masa pandemi apakah siswa mengembangkan bakat } \\
\text { olahraganya }\end{array}$ & $47,4 \%$ & $81,6 \%$ \\
\hline 3 & $\begin{array}{l}\text { Siswa kurang termotivasi untuk mengikuti Pendidikan jasmani secara } \\
\text { daring. }{ }^{*}\end{array}$ & $73,7 \%$ & $60,5 \%$ \\
\hline 4 & $\begin{array}{l}\text { Siswa hanya menyukai pada pembelajaran Pendidikan jasmani yang } \\
\text { jenisnya permainan.* }\end{array}$ & $73,7 \%$ & $71,1 \%$ \\
\hline 5 & $\begin{array}{l}\text { Siswa tidak fokus saat pembelajaran pendidikan jasmani secara } \\
\text { daring. }{ }^{*}\end{array}$ & $63,2 \%$ & $63,2 \%$ \\
\hline 6 & $\begin{array}{l}\text { Siswa bersemangat dalam mengikuti pembelajaran PJOK secara } \\
\text { daring }\end{array}$ & $73,7 \%$ & $61,8 \%$ \\
\hline 7 & Siswa berperan aktif pada saat pembelajaran daring berlangsung & $78,9 \%$ & $61,8 \%$ \\
\hline 8 & Tidak semua contoh yang diberikan guru dilakukan siswa. ${ }^{*}$ & $73,7 \%$ & $80,3 \%$ \\
\hline 9 & Semua pertanyaan siswa dapat dijawab oleh guru & $89,5 \%$ & $90,8 \%$ \\
\hline 10 & $\begin{array}{l}\text { Untuk mengajar PJOK di tingkat SMP, tingkat Pendidikan guru } \\
\text { S1 }\end{array}$ & $84,2 \%$ & $77,6 \%$ \\
\hline 11 & $\begin{array}{l}\text { Untuk mengajar PJOK di tingkat SMP, guru harus lulusan dari } \\
\text { Pendidikan Jasmani Kesehatan dan Rekreasi }\end{array}$ & $89,5 \%$ & $86,8 \%$ \\
\hline 12 & Guru lambat dalam merespon pertanyaan siswa. ${ }^{*}$ & $84,2 \%$ & $76,3 \%$ \\
\hline 13 & Guru mengajar tepat waktu sesuai jadwal & $94,7 \%$ & $72,4 \%$ \\
\hline 14 & Guru menggunakan media video dalam pembelajaran daring & $84,2 \%$ & $61,8 \%$ \\
\hline 15 & Saat pemberian contoh guru menggunakan alat peraga & $84,2 \%$ & $61,8 \%$ \\
\hline 16 & $\begin{array}{l}\text { Guru menggunakan metode yang bervariasi dalam pembelajaran } \\
\text { daring }\end{array}$ & $73,7 \%$ & $64,5 \%$ \\
\hline 17 & $\begin{array}{l}\text { Guru memodifikasi media dalam pembelajaran dari sehingga } \\
\text { pembelajaran menyenangkan }\end{array}$ & $94,7 \%$ & $59,2 \%$ \\
\hline 18 & Seluruh materi yang ada di standar isi dan standar kelulusan & $84,2 \%$ & $68,4 \%$ \\
\hline
\end{tabular}


disesuaikan dengan kondisi khusus

\begin{tabular}{|c|c|c|c|}
\hline 19 & $\begin{array}{l}\text { Alokasi waktu dalam pembelajaran disesuaikan dengan kondisi } \\
\text { khsus }\end{array}$ & $89,5 \%$ & $81,6 \%$ \\
\hline 20 & $\begin{array}{l}\text { Guru mengajar sesuai dengan standar kompetensi dan kompetensi } \\
\text { dasar }\end{array}$ & $89,5 \%$ & $81,6 \%$ \\
\hline 21 & $\begin{array}{l}\text { Format silabus dan RPP sesuai dengan ketentuan dari } \\
\text { Permendiknas No } 22 \text { Tahun } 2006\end{array}$ & $84,2 \%$ & $93,4 \%$ \\
\hline 22 & Guru menggunakan prinsip progresif dalam proses pembelajaran & $89,5 \%$ & $89,5 \%$ \\
\hline 23 & Guru memberikan materi secara berkesinambungan & $94,7 \%$ & $90,8 \%$ \\
\hline 24 & Siswa memiliki alat komunikasi ( handphone, dan leptop) & $57,9 \%$ & $52,6 \%$ \\
\hline 25 & Siswa dapat menggunakan alat komukasi (handphone, dan leptop) & $68,4 \%$ & $73,7 \%$ \\
\hline 26 & $\begin{array}{l}\text { Guru menggunakan aplikasi daring (whatsap, google classroom, } \\
\text { ruang guru, dan zoom) }\end{array}$ & $84,2 \%$ & $86,8 \%$ \\
\hline 27 & $\begin{array}{l}\text { Tidak semua guru dapat menggunakan aplikasi daring (whatsap, } \\
\text { google classroom, ruang guru, dan zoom. }{ }^{*}\end{array}$ & $89,5 \%$ & $56,6 \%$ \\
\hline 28 & Akses internet di daerah tempat tinggal siswa lacar & $47,4 \%$ & $47,4 \%$ \\
\hline 29 & Akses internet di daerah tempat tinggal guru lancer & $73,7 \%$ & $65,8 \%$ \\
\hline 30 & Seluruh siswa mendapat bantuan paket internet dari pemerintah & $73,7 \%$ & $71,1 \%$ \\
\hline & Total & 2373,8 & 2182,9 \\
\hline & Rata-rata & $79,1 \%$ & $72,8 \%$ \\
\hline
\end{tabular}

Dari hasil analisis 30 pernyataan yang di jawab guru bila dirata-ratakan memperoleh rata-rata $79,1 \%$. Bila dikonversikan pada tabel skala penilaian berada pada kategori "sedang". Sedangkan hasil analisis 30 pernyataan yang dijawab siswa bila dirata-ratakan memperoleh rata-rata $72,8 \%$. Bila dikonversikan pada tabel skala penilaian berada pada kategori "sedang".

Berdasarkan rata-rata yang diperoleh pada setiap komponen indikator keterlaksanaan pembelajaran PJOK pada masa pandemi Covid-19 dari 95 orang sampel dalam penelitian memperoleh rata-rata keterlaksanaan pembelajaran PJOK berbasis daring tingkat SMP di Kabupaten Bangli pada masa pandemi Covid-19 sebagai berikut:

$$
\begin{aligned}
\text { Rata-rata } & =\frac{\bar{X} 1+\bar{X} 2}{2} \\
= & (79,1+72,8) / 2 \\
= & 75,9 \%
\end{aligned}
$$

Berdasarkan kedua jawaban yang di berikan oleh guru dan siswa mengenai keterlaksanaan pembelajaran PJOK berbasis daring tingkat SMP di Kabupaten Bangli diperoleh rata-rata sebesar $75,9 \%$. Bila dikonversikan ke dalam tabel skala penilaian berada pada kategori "Sedang".

\section{Pembahasan}

Berdasarkan 30 penjabaran pernyataan yang diberikan kepada guru dan siswa. Hasil jawaban guru bila dirata-ratakan diperoleh hasil 79,1\% dan hasil jawaban dari siswa bila dirataratakan sebesar $72,8 \%$. Hasil jawaban guru dan siswa bila dirata-ratakan sebesar $75,9 \%$ apabila dikonversikan pada tabel skala penilaian hasil jawaban guru dan siswa berada pada kategori "Sedang".

Wabah corona virus disease 2019 (Covid-19) yang telah melanda 215 negara di dunia, memberikan tantangan tersendiri bagi lembaga pendidikan. Untuk mencegah penyebaran Covid-19 Pemerintah telah melarang untuk berkerumun, pembatasan sosial (social distancing) dan menjaga jarak fisik (physical distancing), memakai masker dan selalu cuci tangan. Melalui Kementerian Pendidikan dan Kebudayaan Pemerintah telah melarang pembelajaran untuk tatap muka dan memerintahkan untuk menyelenggarakan pembelajaran secara daring.

Kementerian Pendidikan dan Kebudayaan Republik Indonesia memperkirakan 34,5 persen siswa tidak dapat mengakses pendidikan dimasa pandemi. Upaya signifikan dilakukan oleh pemerintah dan lembaga pendidikan di semua tingkatan untuk menemukan solusi praktis dalam pembelajaran dirumah di tengah wabah COVID-19(Raibowo \& Nopiyanto, 2020) 
Pembelajaran di rumah yang membatasi interaksi fisik mengakibatkan tidak adanya interaksi sosial, sehingga komunikasi verbal dan non verbal tidak digunakan dengan benar

Sebuah penelitian menunjukkan bahwa ketika siswa tidak berada di sekolah, misalnya, liburan atau belajar di rumah, mereka secara fisik kurang aktif dan memiliki waktu yang lebih lama untuk menggunakan ponsel, sehingga penggunaannya juga akan terasa jenuh, bahkan dengan stres yang berat dan ringan. (Bangun, 2019).

Penelitian yang dilakukan oleh Raibowo(Raibowo \& Nopiyanto, 2020) dengan judul proses belajar mengajar PJOK di masa pandemi dengan hasil menjunjukan bahwa proses belajar mengajar di masa pandemi covid-19 tingkat SMA se-Kota Bengkulu berada pada kategori "sangat rendah" sebesar $8 \%$, "rendah" sebesar $46 \%$, "sedang" sebesar " $15 \%$, "tinggi" sebesar $26 \%$ dan "sangat tinggi" $5 \%$. Berdasarkan nilai rata-rata, yaitu 79,59 , porses belajar mengajar PJOK di masa pandemi covid-19 tingkat SMA se-Kota Bengkulu berada pada kategori "rendah".

Penelitian yang dilakukan oleh(Rochman et al., 2020) dengan judul identifikasi keterlaksanaan pembelajaran PJOK tingkat SMP di masa pandemi covid-19 se-kabupaten Sidoarjo dengan hasil menunjukan pada kategori "sangat rendah" sebesar $8 \%$ (8 guru), "rendah" sebesar 15.0\% (15 guru), "sedang" sebesar 46\% (46 guru), "tinggi" sebesar 26.0\% (26 guru), dan "sangat tinggi" sebesar $5 \%$ (5 peserta didik). Berdasarkan nilai rata-rata, yaitu 89.62, identifikasi tingkat keterlaksanaan pembelajaran PJOK tingkat SMP di Masa Pandemi COVID19 seluruh guru olahraga SMP se-Kabupaten Sidoarjo berada pada tingkatan "sedang".

Berdasarkan data-data penelitian di atas, beberapa penelitian yang terkait menunjukan bahwa pelaksanaan pembelajaran secara daring pada masa pandemi covid-19 pada materi PJOK berjalan dengan kategori rendah dan sedang. Dalam pelaksanaan pembelajaran pendidikan jasmani olahraga dan kesehatan terdapat tiga kompetensi pokok guru yaitu perencanaan, pelaksanaan, dan evaluasi. Sebagian guru PJOK hanya mempunyai kompetensi dalam perencanaan. Sedangkan kompetensi PJOK yang lain dalam pelaksanakan dan evaluasi pendidikan jasmani, tidak sepenuhnya sesuai dengan teori yang ada, ini menunjukkan bahwa keefektifan pembelajaran PJOK masih mengalami banyak kendala Sehingga hal ini menyebabkan peroses pembelajaran PJOK belum bisa berjalan dengan maksimal.

\section{SIMPULAN DAN SARAN Simpulan}

Hasil survey keterlaksanaan pembelajaran PJOK berbasis daring tingkat SMP di Kabupaten Bangli pada masa pandemi Covid-19 diperoleh dengan menggunakan angket. Dan berdasarkan hasil analisis data bawa tingkat keterlaksanaan pembelajaran PJOK berbasis daring tingkat SMP di Kabupaten Bangli pada masa pandemi Covid-19 bila dikonversikan ke dalam sekala penilaian berada pada kategori "Sedang" mencapai 75,9,\%. Dengan demikian dapat disimpulkan bahwa keterlaksanaan pembelajaran PJOK berbasis daring tingkat SMP di Kabupaten Bangli pada masa pandemi Covid-19 terlaksana namun belum maksimal.

\section{Saran}

Berdasarkan hasil penelitian maka saran yang dapat diberikan adalah sebagai berikut:

1. Bagi Institusi Pendidikan

Dengan adanya penelitian ini diharapkan dapat bermanfaat untuk pengembangan ilmu pengetahuan serta memberikan informasi ilmu Pendidikan khususnya pada Pendidikan olahraga di masa pandemi Covid-19 ini.

2. Bagi Guru PJOK

Dengan adanya penelitian ini diharapkan bagi pendidik ataupun calon pendidik lebih kreatif dan inovatif selama pemberian pembelajaran PJOK secara daring serta lebih menguasai dalam menggunakan aplikasi dan mendia daring. 
3. Bagi Penelitian Selanjutnya

Dengan adanya penelitian ini daharapkan dapat menambah refrensi bagi penelitian selanjutnya terkait dengan keterlaksanaan pemebelajaran PJOK pada masa pandemi Covid-19. Peneliti selanjutnya juga dapat mengembangkan variabel-variabel yang lain.

\section{DAFTAR PUSTAKA}

Bangun, S. Y. (2019). Peran Pelatih Olahraga Ekstrakurikuler Dalam Mengembangkan Bakat Dan Minat Olahraga Pada Peserta Didik. Jurnal Prestasi, 2(4), 29-37.

Candra, F. A. (2021). PENERAPAN METODE DARING, LURING DAN HOME VISIT DI KELAS V UPT SPF SDN 106828 SUMBERJO DI MASA PANDEMI COVID-19. Prosiding Seminar Nasional, 1(1).

Kanca, I. N. (2010). Metode Penelitian Pengajaran Pendidikan Jasmani dan Olahraga. Singaraja: Universitas Pendidikan Ganesha.

Nakayama, M., Yamamoto, H., \& Santiago, R. (2007). The Impact of Learner Characteristics on Learning Performance in Hybrid Courses among Japanese Students. Electronic Journal of E-Learning, 5(3), 195-206.

Pohan, A. E. (2020). Konsep pembelajaran daring berbasis pendekatan ilmiah. Penerbit CV. Sarnu Untung.

Rahayu, E. T. (2013). Strategi Pembelajaran Pendidikan Jasmani: Implementasi pada Pembelajaran Pendidikan Jasmani. Olahraga Dan Kesehatan, Bandung: Alfabeta.

Raibowo, S., \& Nopiyanto, Y. E. (2020). Proses Belajar Mengajar Pjok Di Masa Pandemi Covid-19. STAND: Journal Sports Teaching and Development, 1(2), 112-119.

Rochman, B., Indahwati, N., \& Priambodo, A. (2020). Identifikasi Keterlaksanaan Pembelajaran PJOK Tingkat SMP Di Masa Pandemi Covid 19 Se-Kabupaten Sidoarjo. Jurnal IImiah Mandala Education, 6(1).

Sari, W., Rifki, A. M., \& Karmila, M. (2020). Analisis kebijakan pendidikan terkait implementasi pembelajaran jarak jauh pada masa darurat covid 19. Jurnal Mappesona, 2(2).

Sudijono, A. (2001). Pengantar evaluasi pendidikan. 